\title{
Bauxite Mining in Eastern Ghats of Andhra Pradesh, Possible Environmental Implications and Measures for Environmentally Friendly Mining
}

\author{
M. Jagannadha Rao ${ }^{1}$, Ch. Hanuman Prasad ${ }^{2}$ Mustefa Mohammad $^{3}$, Asif Iqbal Kakkassery ${ }^{4}$ \\ 1, 2, 3, 4 Department of Geology, Andhra University, Visakhapatnam-530003, AP, India
}

\begin{abstract}
India is blessed with huge resources of bauxite distributed in different states of the country. Out of these deposits, the bauxite resources found in Eastern Ghats especially in Odisha and Andhra Pradesh are known for their quality and quantity. The state of Andhra Pradesh is estimated to be having bauxite resources of nearly one thousand million tons and make the state as a $2^{\text {nd }}$ largest resource base for bauxites in India. Recent policy of the government of Andhra Pradesh is to open up bauxite mining in the Eastern Ghat terrain. This raised a controversy, since the local tribes and some NGOs are strongly opposing such mining, with apprehension of impacts on environment, including pollution of waters bodies, pollution of soil, deforestation causing effects on rare flora and fauna etc. They have further objections on the mining activity, since they felt, that it may affect the very culture of the native tribes, their life style their resources etc. Under this context this paper is attempted to present the possible impacts of mining in case of active mining initiatives of bauxite in this region. It further examines the peoples'apprehensions related to impacts on environment and tribal socioeconomic and cultural implications. An attempt is made to suggest the possible remedial measures for environmentally friendly mining of these resources with minimum impact on the environment including the sensitive forest cover, land, water, tribal culture etc.
\end{abstract}

Keywords: Bauxite, Mining, Eastern Ghats, Environment.

\section{Introduction}

Bauxite is a naturally occurring, heterogeneous material composed primarily of one or more aluminum hydroxide minerals, plus various mixtures of silica, iron oxide, titania, aluminum silicates, and other impurities in minor or trace amounts. Bauxite is called as a ore produced by residual weathering or in situ chemical weathering typically under tropical to subtropical climatic conditions. The principal aluminum hydroxide minerals found in varying proportions with bauxites are gibbsite and the polymorphs boehmite and diaspore. Bauxites are typically classified according to their intended commercial application: abrasive, cement, chemical, metallurgical, refractory, etc.The bulk of world bauxite production (approximately 85\%) is processed into aluminum oxide $\left(\mathrm{Al}_{2} \mathrm{O}_{3}\right.$, also known as alumina) via a wet chemical, caustic leach method (the Bayer process). The resulting $\mathrm{Al}_{2} \mathrm{O}_{3}$ is then reduced to aluminum metal (Al) using an electrolytic process, the Hall-Heroult process. .Bauxite is the raw material most widely used in the production of aluminum on a commercial scale. Bauxite is a light mineral; its specific gravity is 2.6 to 3.5 . It is usually, an amorphous or clay like substance which is, however, not plastic. The usual color of bauxite is pink, but if of low iron content it may tend to become whitish in color and with increase in iron it becomes reddish brown in color.It is well known that when alumina-rich igneous rocks/metamorphic rocks weather the feldspars of such rocks are usually kaolonized, but under tropical monsoonal conditions, the weathering goes a step further and results in residuum rich in hydroxides of aluminum together with oxides of iron, manganese and titanium. Where there is a sufficient concentration of the aluminum hydroxides, economic deposits of bauxite originate. This process of "bauxitization" as it is called thrives well on a topographically elevated well-drained place and that is why, most bauxite deposits occur, on large plateau, of low relief. In the world, bauxite deposits have been found in rocks of Tertiary age, Mesozoic age, and even in Paleozoic age.

The bauxite deposits of India are reported of diverse parentage. The bauxite deposits are associated with khondalite and charnockite group of rocks in Eastern Ghats (Ramam, 1978, Ramam \& Vaidyanathan, 1978, Hanuman prasad, 2010) with granite gneisses in Western Ghats (Radhakrishna 1965, Viswanathaiah et al 1974). Kerala bauxites on the west coast are derived from charnockites, gneisses and amphibolites (Fox 1936, Dey 1954, Stephens 1961). The bauxite deposits of Madhya Pradesh were derived from Deccan trap basalts (Fox 1923, Chatterjee 1951, Roy Chowdary 1958). On the basis of structural, mineralogical and Lithological evidences, Ghosh and Dutta suggested derivation of Phutkapahar bauxites of Madhya Pradesh from Gondwana sandstones. In Uttar Pradesh bauxites, are derived from upper Vindhyan sandstones (Swarup 1973). The bauxites deposits of Jammu province are unique in the country as they are high silica diaspore type and they are present as isolated pockets on the northern slopes of Sirban limestone (Mohanlal et al 1979).

\section{Bauxite in Andhra Pradesh}

Andhra Pradesh is 2nd richest in bauxite deposits in the country. Reserves of 750 to 1000 million tons of metal-grade bauxite have been proved in forest and tribal tracts of Visakhapatnam, East Godavari and Vizianagaram districts, crowning the Eastern Ghat hill ranges. These deposis are mainly derived from khondalite hills of the Eastern GhatSupergroup (Archean). These bauxite deposits in the State occur mostly atop the Eastern Ghat ranges in East Godavari (Addatigala, Chidipalem, Gurtedu, Katamrajkonda, PeddaAddapalli and Y.Ramavaram), Visakhapatnam (Anantagiri, Paderu, Araku, Chintapalli and Sunkarimetta) and Vizianagaram districts. They are called as 


\section{International Journal of Science and Research (IJSR) \\ ISSN (Online): 2319-7064 \\ Index Copernicus Value (2013): 6.14 | Impact Factor (2015): 6.391}

East Coast Bauxite deposits of India as they are close to the proximity of Eastern Coastline. The contribution from Andhra Pradesh to the country's in situ bauxite reserve is about $20 \%$. The aerial spread of the deposits range between $0.1 \mathrm{Km}^{2}$ and $15 \mathrm{Km}^{2}$ and thickness developed up to a maximum of $54 \mathrm{~m}$. The bauxite is characterized by low silica $(<5 \%)$, low Titania $(<2 \%)$ and high iron (8-28\%). Alumina content ranges between 42 and $52 \%$ in general. Gibbsite is the major aluminous mineral.

Various industries have prepared feasibility reports for mining and for establishing alumina plants near the vicinity of Visakhapatnam port. All bauxite deposits are located in proximity to the fast growing Visakhapatnam port.

APMDC a governmental body is offering joint ventures for mining Bauxite to industrialists, who intend to set up Alumina/ Aluminum plants. Power being a major component and infrastructure in the manufacture of Alumina / Aluminum, facilities like allotment of coal mines for captive power generation can be made available for immediate take off. In Andhra Pradesh, aluminous laterite capping the khondalitic suite of rock have been located in the Dumkonda, Sapparla hills in the east Godavari and Korukonda, Galikonda, Raktakonda, Katuki, Chittamgundi, areas in Visakhapatnam district. The Galikonda bauxite is of the gibbsitic type and is red, reddish-brown, pink or yellowish-brown in color, massive and moderately hard: no pisolitic or oolitic textures are noticed. This bauxite caps garnet-sillimanite gneiss

The distribution of these deposits is shown. (Fig-1, Fig-2)

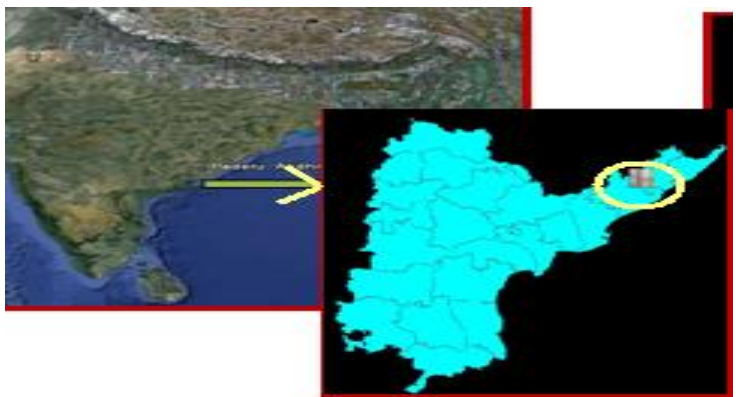

Figure 1: Location of Bauxite Deposits in AP

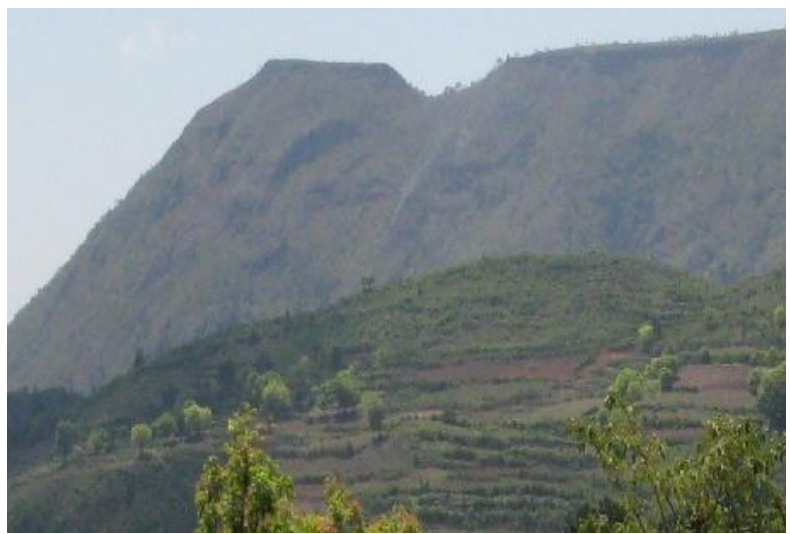

Figure 2: Galikonda Bauxite Deposit of the study area

\section{The Contention}

The aspect of mining of bauxite deposits from parts of Eastern Ghats in Andhra Pradesh have been issue of contention between the successive governments and organizations representing the local tribes. The agitations and legal battles between these two parties for over two decades are masking the prospects of active mining and processing of these valuable resources. The government of newly formed state of Andhra Pradesh has decided to open up bauxite mining in Eastern Ghats for the economic development of the region as well as the state. The government felt, that the judicious use of these resources will help the government financially and also benefit the people by providing employment and developing the region by providing infrastructure by way of roads, railway lines, educational institutions, health care and overall socio economic development of the mining district.

\section{The Possible Impacts}

The apprehensions of the people against mining need to be examined in the realistic sense. Any mining activity is bound to have impacts on environment and bauxite mining is of no exception. The ecosystems of the terrain where bauxite is occurring is endowed with lush green forests, valleys, waterfalls, and the resident native tribes. (Figs 3a to Fig 3c)

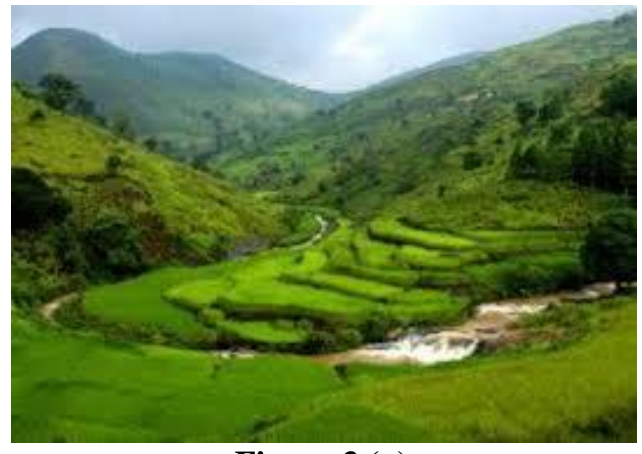

Figure 3 (a)

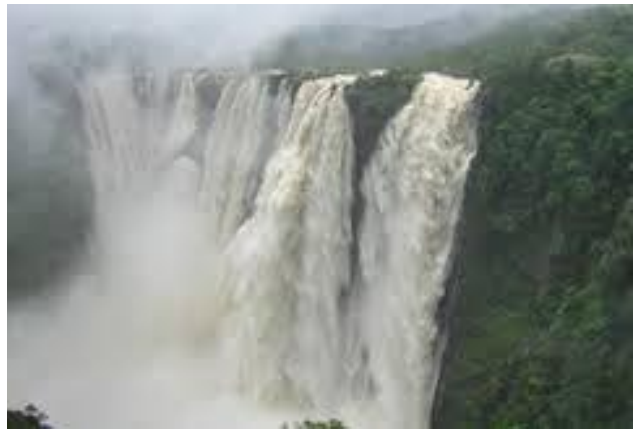

Figure 3 (b)

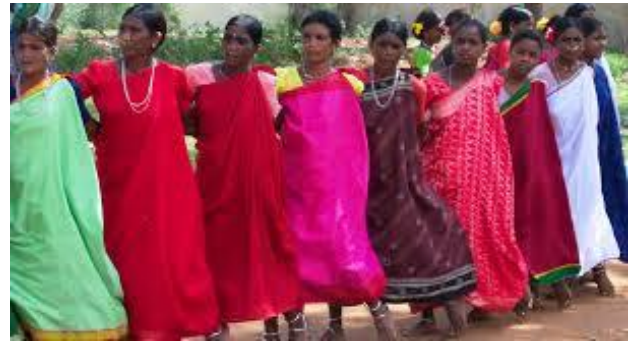

Figure 3 (c) 


\section{International Journal of Science and Research (IJSR) \\ ISSN (Online): 2319-7064 \\ Index Copernicus Value (2013): 6.14 | Impact Factor (2015): 6.391}

*The study area with lush green valley's (Fig3a), Marvelous water falls (Fig-3b) and local Tribes in their traditional dance (Fig-3c)*

Mining can have adverse effects on surrounding surface and ground water, if protective measures are not taken. Runoffs of rock debris although non-toxic also effect the surrounding vegetation. The dumping of the runoff in surface water is the worst option in mine site. Disposal of tailings after treatment is regarded as a better option. Land storage and refilling of the mine after it has been depleted is even better, if no forests need to be cleared for massive contamination of the area surrounding mines due to the various chemicals used in the mining process as well as the potentially damaging compounds and metals removed from the ground with the ore. Large amount of water produced from mine drainage, mine cooling, aqueous extraction and other mining processes increases the potential for these chemicals to contaminate ground and surface water. In well-regulated mines, hydrologist and geologist have to take careful measurements of water and soil to exclude any type of water contamination that could be caused by the mine's operations.

Bauxite is generally mined by opencast or strip mining. Heavy machinery is used to move the earth to produce the mineral. This will cause an immediate impact on the environment. Open cast mining involves removing the top layer of soil in order to reach the ores underneath. The resultant soil erosion results in the difficulty for vegetation be it natural or crop, to re-establish itself. This is especially true if the removed soil is not replaced soon after the mining operation is finished. Some mining companies have a better record of reducing soil erosion than others.

Bauxite residue popularly known as red mud mixed with caustic soda may be a threat to the environment and also needs huge acreage of lands for maintaining red mud ponds in the mining and processing vicinity. Now during recent technological development the red mud is successfully and safely recycled and used in industries like cement. In fact, many of the cement units in AP are using it. The world's first red mud powder cement plant has come up at Lanjigarh refinery in Odisha.

\section{The Remedial Measures}

The government and the industry should initiate the mining cautiously, the first step is to consider the peoples' apprehensions and clarify their doubts related to the possible destruction of the ecosystem etc. A technical committee has to be setup to investigate thoroughly to generate the base line environmental data pertaining to the ecosystem surrounding these deposits. This should include data on soil cover, surface water, ground water, flora and fauna. The data should be used to check the condition of environment time to time during the progress of mining and processing to assess the impact on environment if any. The impacts disused above need to be considered and the scientific remedies should be made available like a contingent plan for all the companies involved in mining.

The bauxite mining will be basically done by opencast mining method. The possible impacts and required remedial measures are discussed below. The open cast mining method, being most suitable for these deposits is to be operated at these mines. Due to open cast mining, two severe problems arise, firstly the removal of top soil cover and secondly dumping of overburden. The loss of top soil cover is a major problem and should be minimized by scrapping of the upper layer in a manner that it can be laid elsewhere as a uniform layer. Top soil of the area which is to be used as dumping place for the overburden has also be removed and replaces. Replacement of top soil on the earlier dumped over burden is one of the possible solutions.

The other impact of open cast mining activity is development of hollows in the earth, a proper planning of the mining activity i.e. dumping of overburden in the excavated portions of mines would help in reclaiming the land earlier used for exploitation.

Afforestation on the reclaimed land is another important measure to be followed for maintaining the biodiversity and ecosystem.

Another problem involved with opencast mining is generation of dust due to operation of heavy machines such as dumpers, loaders and drilling machines, the dust generation is controlled by sprinkling of water at regular intervals. The water stored in the deep quarries during monsoon season is best utilized for this purpose.

A significant percentage of profits should be charged from the companies as an environmental cess and should be kept available to an authorized autonomous committee to take up environmental restoration on continuous basis. This committee should be headed by a responsible nongovernmental official and manned by environmentalists, NGO's and peoples' representatives.

The government should consider visiting the counties like Jamaica Guneaetc, where the bauxite mining has been in progress for a last several years. The successful remedies adopted by these countries with respect to protection of environment should be followed in our case also. The impact already experienced in bauxite mining in adjacent Odisha should be taken into consideration as a preventive measure, since the geological environment of these two areas are similar.

\section{Conclusion}

The valuable resources of bauxite of Eastern Ghats of AP can be mined in environmentally friendly way by commitment towards the wellbeing of environment by following established remedial measures and plans.

\section{References}

[1] Chatterjee, P.K., 1951. Bauxite deposits of Korba and uproar Xamindaries and adjacent parts in M.P., Indian Minerals, Vol. 1, pp25-30

[2] Dey, A.K., in 1954 Observation on Buchanan's laterite of Malabar, Jour. Min. Geol. Met. Ind., Vol. 47 ( 2) pp 129-133.

[3] Fox, C.S., 1936. Buaxite and aluminous laterite. Technical press. London. 


\section{International Journal of Science and Research (IJSR) \\ ISSN (Online): 2319-7064}

Index Copernicus Value (2013): 6.14 | Impact Factor (2015): 6.391

[4] Fox, C.S., 1923. The bauxite and aluminium laterite occurrences in India. Geol. Surv. Ind. Mem., Vol. 49, Pt1.

[5] Hanuman Prasad .Ch (2010) "Evaluation of bauxite deposits from parts of Eastern Ghats, AP, using, RS and GIS tools" unpublished, Ph.Dthesis submitted to Andhra University.

[6] Mohanlal, Jamwal, J.S and Nanda, M.M., 1979. Bauxite deposits of Jammu, India. Inter. Sem. Later. Proc., Trivasndrum, India, pp-190192.

[7] Roy Chowdary, M.K. 1958 Bauxite in Bihar, M.P., Vindhya Pradesh, Madhya Bharat and Bhopal. Mem. Geol. Surv. India. Vol.85, pp-1-271

[8] Ramam P.K (1978):- "Bauxite residuum derives from Khondalite \& Charnockite. Jour. Of Geol. Soc. India. Vol 19(4). PP.181-182.

[9] Ramam P.K \&Vaidyanathan R (1978):- "Laterite and Lateritisation over Eastern Ghats and Coastal Plains in North Coastal A.P, India. Proc. Int. Symp. Lateritisation process India. PP.295-301.

[10] Radhakrishna, B.P., 1965. Occurrences of bauxite along west coast of Mysore state, South India, Jour Geol. Soc. India Vol. 6, pp-62-66.

[11] Stephens, C.G., in 1961. Pedogenesis following the dissection of laterite regions of Southern Australia( CSIRO) Art. Bull., No-206

[12] Swarup, P., 1973. Mineralogy and Origin of the Rajahuan bauxite deposits. Jr. Geol. Soc. Ind., Vol-14, pp-169-177

[13] Viswanathaiah et al 1974. Bauxite of Paduvare area South Kanara, Karnataka. Ind. Mineralogist.15, pp-6373 